\title{
Comparative Analysis of Hazelnut Farming Enterprises' Approach to Agricultural Insurance: Case Study of Duzce Province
}

\author{
Harun Kabaoglu (Corresponding author) \\ Provincial Agriculture and Forestry Directorate, Duzce, Turkey \\ E-mail: harun.kabaoglu@tarimorman.gov.tr
}

Avni Birinci

Ataturk University, Faculty of Agriculture, Department of Agricultural Economics, 25240 / Erzurum, Turkey

E-mail: abirinci@atauni.edu.tr

\begin{abstract}
This research was carried out in order to compare the individual characteristics of the producers with and without the agricultural insurance, the structural characteristics of the hazelnut manufacturing enterprises and the characteristics of the information sources, and to show the similarities and differences between them in all the provinces of Duzce province where hazelnut production is concentrated. Duzce province center and 7 provinces were interviewed face to face in 2016 with a total of 319 producers selected by simple random sampling method, of which 96 had agricultural insurance and 223 had no agricultural insurance, and the result of the survey the proportional distributions of the obtained data were made. As a result of the analysis, the ratio of the high income group was $2.7 \%$ among those who did not have the agricultural insurance but this rate was found to be $26 \%$ in the insured of agriculture insured. Among those who did not receive agricultural insurance, the rate of those who suffered from agricultural disaster was $31,8 \%$, while this rate was $82,3 \%$ for those who have agricultural insurance. While the ratio of those who use agricultural loans in those who do not have agricultural insurance is $50,2 \%$, this ratio is $78,1 \%$ in those who have agricultural insurance.
\end{abstract}

Keywords: Survey, Duzce, hazelnut, agricultural insurance

DOI: $10.7176 / \mathrm{JSTR} / 5-4-19$

\section{Fındık Üretimi Yapan İşletmelerin Tarım Sigortasına Olan Yaklaşımlarının Karşılaştırmalı Analizi: Düzce İli Örneği ${ }^{1}$}

\begin{abstract}
Özet: $\mathrm{Bu}$ araştırma, findık üretiminin yoğun olarak yapıldığı Düzce iline bağlı tüm ilçelerde, tarım sigortası yaptıran ve yaptırmayan üreticilerin bireysel özellikleri, findık üretimi yapan işletmelerin yapısal özellikleri ve bilgi kaynaklarına yaklaşım özellikleri açısından karşılaştırmak ve aralarındaki benzerlik ve farklılıkların ortaya konulması amacıyla yapılmıştır. Düzce il merkezi ve 7 ilçede findık üretimi ile iştigal eden 96'sı tarım sigortası yaptıran, 223'ü ise tarım sigortası yaptırmayan olmak üzere basit tesadüfi örnekleme yöntemi ile seçilen toplam 319 üretici ile 2016 yılında sahada yüz yüze görüşmek suretiyle anket çalışması gerçekleştirilmiş ve anket sonucu elde edilen verilerin oransal dağılımları yapılmıştır. Yapılan analizler sonucunda, tarım sigortası yaptırmayanlarda yüksek gelir grubuna mensup oranların oran $\% 2,7 \mathrm{iken}$, bu oran tarım sigortası yaptıranlarda \%26 olarak tespit edilmiştir. Tarım sigortası yaptırmayanlarda tarımsal afetten zarar görenlerin oranı $\% 31,8$ iken, bu oran tarım sigortası yaptıranlarda \%82,3 olarak belirlenmiştir. Tarım sigortası yaptırmayanlarda tarımsal kredi kullananların oranı \%50,2 iken, tarım sigortası yaptıranlarda bu oranın \% 78,1 olduğu sonucuna varılmıştır.
\end{abstract}

Anahtar Kelimeler: Anket, Düzce, fındık, tarım sigortası

\footnotetext{
${ }^{1}$ Bu çalışma Prof. Dr. Avni Birinci danışmanlı̆̆ında, Harun Kabaoğlu tarafindan, Atatürk üniversitesi Fen Bilimleri Enstitüsü Tarım Ekonomisi Anabilim dalında yapılan "Fındık Üreticilerinin Tarım Sigortası Yaptırmaya Karar Verme Sürecinde Etkili Olan Faktörlerin Analizi: Düzce İli Örneği” isimli yüksek lisans tezinden üretilmiştir.
} 


\section{Giriş}

Tarım, ülke insanının gıda ihtiyacını karşılaması, ekonomiye ve istihdama katkısı, sanayinin hammadde ihtiyacını karşılaması, ihracata katkıda bulunması gibi başlıca temel nedenlerden dolayı, ekonominin vazgeçilmez bir sektörüdür (Keskinkılıç 2013).

Tarım sektörünün önemli sektörlerin başında olduğu Türkiye'de, üreticilerin, üretim periyotları boyunca ürünlerini risklere karşı korumaları büyük önem arz etmektedir. Üreticilerin ürünlerini risklere karşı korumak için sigorta mekanizmasının devreye girmesi gerekmektedir.

Sigorta kavramı en genel ifadeyle; "bireylerin ve işletmelerin, gelecekte karşılaşabilecekleri olası risklerin olumsuz sonuçlarını ortadan kaldırmak ya da azaltmak amacıyla oluşturulmuş bir risk yönetim sistemi" şeklinde tanımlanabilir (Keskinkılıç 2013).

Tarımsal üretimi olumsuz etkileyen başta don, dolu, kuraklık, sel, deprem, firtına ve benzeri doğal afetlerin meydana gelmesi ile üreticilerin gelirlerinde önemli kayıplar yaşanmakta, gelirlerde istikrarsızlığa neden olarak üretimin sürdürülmesi kesintiye uğramaktadır. Bu ve benzer nedenlerle üreticiler ssk sık meydana gelen doğal afetler sonucunda tarımsal üretimden soğumakta ve zamanla üretim yapmaktan vazgeçmektedir.

Dünya'da modern anlamda ilk tarımsal sigorta uygulamaları 1770-1800 yılları arasında Avrupa'da başlamıştır. İlk kez Almanya'da dolu ve yangın sigortaları, İrlanda'da ise hayvan sigortaları yapılmıştır. Ancak yapılan ilk uygulamalar, deneyimin yetersizliği nedeniyle başarısız olmuştur. 19. ve 20. yüzyılda, önce Avrupa ve daha sonra Japonya ve ABD gibi ülkelerde daha geniş kapsamlı tarımsal sigorta uygulamaları başlamıştır (Güngör 2006).

Türkiye'de bu alanda yapılan bir çalışmada; 1960-1969 yıllarını kapsayan veriler kullanılarak, tarımsal sigortacılı̆̆ı önemi, tarım sigortalarına neden ihtiyaç duyulduğu, uygulamada olan sigortacılı̆̆ın ihtiyaçlara ne derecede cevap verdiği ve bu alanda nasıl bir uygulama yapılabileceği ortaya koymuştur. Bu çalışma, Türkiye'de tarım sigortaları alanında yapılan ilk çalışmalardan biri olmuştur (Eraktan 1970) Türkiye'deki tarım sigortaları ile ilgili çalışmalar, 1957 yılından itibaren, özel sigorta şirketlerinin, bitkisel ürünlerde sadece dolu riskine karşı sigorta yapmalarıyla başlamıștır. 1960 yılında hayvan, 1984 yılında kümes, 1990 yılında su ürünleri ve 1991 y1lında üzüm bağlarında pilot uygulama olarak don sigortası yapılmaya başlanmıştır. Ancak etkili bir teşvik sistemi ve bağımsız bir yasal zeminin oluşturulamaması nedeniyle başarıya ulaşamamıştır. Tarımsal sigortacılık alanındaki boşluğu doldurmak adına yapılan çalışmalar sonucunda 5363 sayılı "Tarım Sigortaları Kanunu” 21/06/2005 tarihinde, Resmi Gazetede yayınlanarak yürürlüğe girmiştir (Anonim 2017).

Devlet destekli tarım sigortalarında amaç; doğal afet ve hastalıkların, tarım ve hayvancılıkta neden olduğu zararları kısmen de olsa karşılayıp, üreticileri, uzun vadede gelir istikrarına kavuşturarak, üretimde sürdürülebilirliği sağlamaktır.

Üreticilerin bin bir emekle üretmiş oldukları ürünlerinin bir gecede heba olmaması için tarım sigortası yaptırmalarının tarımsal üretimin sürdürülebilirliği için son derece önemlidir. Bu durum araştırmanın önemini ortaya koymakla birlikte üreticilere tarım sigortasının benimsetilmesi konusunda çalışmaların yapılmasını zorunlu kılmaktadır.

2016 yılı verilerine göre Düzce ilinde Çiftçi Kayıt Sistemine kayıtlı toplam işletme sayısı 26766 olup, ortalama işletme büyüklüğü 18,88 dekardır. Toplam tarım alanı 74165 hektar olup, bu alanın \%68'i kayıt altındadır.

Düzce ilinde meyve üretim alanının neredeyse tamamına yakını fındık üretim alanıdır. Düzce ili Türkiye fındık üretim alanının \%8,9'unu oluşturmakta, üretim bakımından ise yıllara göre değişmekle birlikte 2016 yılı TUIK rakamlarına göre 54493 ton ile 4 . sirada bulunmaktadır.

Türkiye'de her yıl yaşanan tabii afetlerden dolayı çiftçiler büyük zarar görmekte ve bu zararlarını karşılayabilmek için devletten çeşitli yardımlar talep etmektedirler. Devletin tarım sigortası uygulamalarının başlaması nedeniyle üreticilerin sadece kredi borçları ertelenmekte, bu durum çiftçileri tatmin etmemektedir.

Çiftçilerin devlet destekli tarım sigortası yaptırmaları durumunda, meydana gelecek bir tabii afette ürün zararlarının büyük bir bölümü tarım sigortası tarafından karşılanacaktır. Bu nedenle Düzce genelinde tarım sigortası yaptıran çiftçilerin sayısının artırılması için tarım sigortası yaptıran ve yaptırmayan çiftçilerin bireysel özellikleri, işletme özellikleri ve bilgi kaynaklarına yaklaşım özelliklerinin bilinmesi büyük önem arz etmektedir. Bu açıdan elde edilen verilerin karşılaştırılması ve aralarındaki benzerlik ve farklılıkların ortaya konulması amacıyla tarım sigortası yaptıran 96 ve yaptırmayan 223 olmak üzere toplam 319 üreticiden anket yöntemi ile veriler toplanmıştır.

\section{Materyal ve yöntem}

2.1. Materyal

Araştırmanın materyalini birincil ve ikincil kaynaklardan derlenen veriler oluşturmuştur. Düzce İlini

184 | P a g e

www.iiste.org 
temsil etmesi bakımından tüm ilçelerdeki fındık üretimi yapan tarım işletmelerinden 319 işletme ile yüz yüze yürütülen anket çalışması sonucu derlenen veriler araştırmanın birincil kaynağını oluşturmuştur. Araştırmanın ikincil kaynakları ise Tarım ve Orman Bakanlığı Düzce İl Müdürlüğü ve TARSİM verileri, konu ile ilgili daha önce yayınlanmış olan derleme, inceleme ve araştırmalardan sağlanmıştır.

\subsection{Yöntem}

Düzce'de findık üretiminin yapıldığı tüm ilçeler olan Düzce Merkez, Akçakoca, Cumayeri, Çilimli, Gölyaka, Gümüşova, Kaynaşlı ve Yığılca ilçeleri araştırma bölgesini oluşturmaktadır. Araştırmanın bu bölgede yapılmasının nedenleri; Türkiye fındık üretiminin yaklaşık \%10'nunu karşlayan ve findık üretimi yapılan en önemli illerin başında gelmesi ve bölgede benzer bir araştırmanın yapılmamış olmasıdır. Bu çalışmada Düzce il genelinde 2016 yılı Çiftçi Kayıt Sistemine kayıtlı 23765 findık üreticisinden örnekleme yoluyla seçilecek çiftçilerle anket yoluyla yüz yüze görüşmeler yapılmıştır. Araştırma kapsamında görüşülecek üretici sayısını belirlemede hem tarım sigortası yaptıran, hem de yaptırmayan üreticilerle anket yapılmasına karar verilmiş olup, anketlerin ildeki genel durumu yansıtabilmesi açısından tüm ilçelerde yapılmasının daha doğru sonuçlar vereceği düşünüldüğünden böyle bir yol seçilmiş̧ir.

Tarım ve Orman Bakanlığı Düzce İl Müdürlüğü kayıtlarından elde edilen veriler ışığında ilçelere göre anket sayısı belirlenmiştir. Anket sayısı Ana Kitle Oranlarına Dayalı Basit Tesadüfi Örnekleme Yöntemi ile tespit edilmiştir. Yöntemde \%95 güven aralı̆̆ ve \%5 hata payı kullanılmıştır (Newbold 1995; Miran 2002).

$$
n=\frac{N p(1-p)}{(N-1) \sigma_{p x}^{2}+p(1-p)}
$$

$\mathrm{Bu}$ formülde;

$\mathrm{n}$ : Örnek büyüklüğ̈̈

$\mathrm{N}$ : Popülasyondaki işletme sayısı

$\sigma_{\mathrm{p}}^{2}$ : Oranın varyans 1

$\mathrm{r}$ : Ortalamadan sapma (\%5)

$\mathrm{Z}_{\alpha / 2}: \mathrm{z}$ cetvel değeri $(1,96)$

$\mathrm{p}$ : Sigorta yaptırmak isteyenlerin olası oranı $(0,3)$

$$
{\sigma_{p}}^{2}=\left(\frac{0,05}{1,96}\right)^{2}=0,000651 \quad n=\frac{23765 * 0,3 * 0,7}{(23764 * 0,000651)+(0,3 * 0,7)}=319
$$

Genel kabul gören olayın gerçekleşme olasılıkları $(\mathrm{p}=0,8$ veya $\mathrm{p}=0,5$ veya $\mathrm{p}=0,3)$ ve gerçekleşmeme olasılığ $(\mathrm{q}=0,2$ veya $\mathrm{q}=0,5$ veya $\mathrm{q}=0,7)$ değerleri dikkate alındığında (Yazıcıŏglu ve Erdoğan 2004), $\% 95$ güven düzeyinde ve $\pm 0,05$ 'lik sapma aralığında:

Sigorta yaptıran üreticiler yaptırmayanlara göre az olmasından dolayı ve belli sayıda ankete ulaşmak için sigorta yaptırmak isteyenlerin olası oranı $\mathrm{p}=0,3$ ve sigorta yaptırmak istemeyenlerin olası oranı ise $\mathrm{q}=1-$ $\mathrm{p}=0,7$ alınmıştır. Üreticilerle yüz yüze görüşülerek yapılan toplam 319 anketin \%30’u, yani 96 adedi sigorta yaptıranlar, \%70'i yani 223 adedi sigorta yaptırmayanlar ile yapılmıştır.

Çizelge 1. İlçelere göre anket sayıları (adet)

\begin{tabular}{lcccccc}
\hline İlçesi & $\begin{array}{c}\text { Fundık } \\
\text { Üretici } \\
\text { Sayısı }\end{array}$ & $\begin{array}{c}\text { Sigorta } \\
\text { Yaptıran } \\
\text { Üretici S. }\end{array}$ & $\begin{array}{c}\text { Sigorta } \\
\text { Yaptırmayan } \\
\text { Üretici S. }\end{array}$ & $\begin{array}{c}\text { Anket } \\
\text { Sayısı } \\
\text { S. } \\
\text { Yaptıran }\end{array}$ & $\begin{array}{c}\text { Anket Sayısı } \\
\text { Sigorta } \\
\text { Yaptırmayan }\end{array}$ & $\begin{array}{c}\text { Toplam } \\
\text { Ornek } \\
\text { Hacmi }\end{array}$ \\
\hline Akçakoca & 7485 & 883 & 6602 & 30 & 70 & 100 \\
Merkez & 3884 & 665 & 3219 & 16 & 36 & 52 \\
Yı̆̆lca & 5172 & 521 & 4651 & 20 & 49 & 69 \\
Gölyaka & 1568 & 321 & 1247 & 6 & 15 & 21 \\
Cumayeri & 2171 & 303 & 1868 & 9 & 20 & 29 \\
Gümüşsova & 1378 & 348 & 1030 & 6 & 12 & 18 \\
Çilimli & 789 & 236 & 553 & 4 & 8 & 18 \\
Kaynaşlı & 1318 & 173 & 1145 & 5 & 13 & $\mathbf{3 1 9}$ \\
\hline Toplam & $\mathbf{2 3 ~ 7 6 5}$ & $\mathbf{3 4 5 0}$ & $\mathbf{2 0 ~ 3 1 5}$ & $\mathbf{9 6}$ & $\mathbf{2 2 3}$ & \\
\hline
\end{tabular}

Kaynak: Anonim 2016a; Anonim 2016b. 
Bu çalışmada veri toplama yöntemi olarak yüz yüze görüşme, veri toplama aracı olarak ise anket formları kullanılmıștr. Anket formları "bireysel özellikler", "işletmelerin yapısal özellikleri”, "bilgi kaynaklarına yaklaşım" olmak üzere üç bölümde sorulan toplam 44 soru ile oluşturulmuştur. Anketler sonucunda ulaşılan veriler SPSS paket programı kullanılmak suretiyle bilgisayar ortamında detaylı analizleri yapılmıştır.

Bu çalışmada, Düzce İl ve İlçelerinde tarım sigortası yaptıran ve yaptırmayan findık üreticilerine uygulanan anket sonuçlarından elde edilen verilerin oransal dağı̆lımları yapılmış ve tarım sigortası yaptıran üreticiler ile yaptırmayan üreticiler arasındaki farklar ortaya konulmuştur.

\section{Araştırma Bulguları ve Tartışma}

\subsection{Fındık üreticilerinin bireysel özellikleri}

Araştırma bölgesinde üreticilerin cinsiyet durumları incelendiğinde, \%6,3'ünün kadın, \%93,7'sinin ise erkeklerden oluştuğu belirlenmiştir. Tarım sigortası yaptıran ve yaptırmayanlarda kadın ve erkek oranı birbirlerine eşit olup, bu oran kadınlarda \%6,3 iken, erkeklerde $\% 93,7$ olduğu tespit edilmiştir.

Üreticilerin evli ve bekar olma durumları incelendiğinde, \%6,6'sının bekar, \%93,4'ünün ise evlilerden oluştuğu, tarım sigortası yaptıranlarda bekar oranı $\% 5,2$ iken, bu oran tarım sigortası yaptırmayanlarda $\% 7,2$ 'dir. Tarım sigortası yaptırmayanlarda evli olanların oranı $\% 92,8 \mathrm{iken}$, tarım sigortası yaptıranlarda bu oranın \%94,8 olduğu belirlenmiştir.

Üreticilerin yaş durumları incelendiğinde, yaklașı \%1'inin 25 yaş altında, \%14'ünün ise genç olarak kabul edilebilecek yaş olan 36 yaş altında oldukları belirlenmiştir. Üreticilerin yaklaşı \% $\% 3$ 'ü orta yaş olarak kabul edilebilecek yaş olan 36-65 yaş arasında, \%13,2‘sinin ise 65 yaşından daha yaşlı oldukları, tarım sigortası yaptırmayan üreticiler içerisinde en yüksek oran ile \%36,3 ile 36-50 yaş grubu üreticilerin oluşturduğu, tarım sigortası yaptıran üreticiler içerisinde ise en yüksek oran ile \%47,9 ile 51-65 yaş grubu üreticilerin oluşturduğu tespit edilmiştir. Tarım sigortası yaptırmayanlar içerisinde genç olarak kabul edilen 36 yaşından küçük olanların oranı yaklaşık \%18 iken, bu oran tarım sigortası yaptıranlarda yaklaşık \%5 civarındadır.

Üreticilerin benimseme davranışları ile yaş arasındaki ilişkiyi belirlemeye yönelik çalışmalarda birbirinden oldukça farklı sonuçlara ulaşıldığı anlaşılmaktadır. Bu amaca yönelik 228 araştırmanın yaklaşık olarak \%50'si bu konuda hiçbir ilişki bulunmadığını ortaya koyarken, \%20'si erken benimseyenlerin daha genç olduklarını, \%30'u ise erken benimseyenlerin daha yaşlı olduklarını göstermiştir (Taluğ ve Tatlıdil 1993).

Üreticilerin eğitim düzeyleri incelendiğinde, yaklaşık \%59'unun okuryazar ve ilkokul mezunu, \%35'inin ortaokul ve lise mezunu, \%5,5'inin ise ön lisans ve lisans mezunu oldukları belirlenmiştir. Diğer bir deyişle üreticilerin yaklaşık $\% 94,5$ 'i lise ve altı eğitim seviyesine sahiptirler. Eğitim durumu tarım sigortası yaptırmayanlarla yaptıranlar arasında benzerlik göstermekte olup, tarım sigortası yaptırmayanlarda lise ve altı eğitim seviyesi yaklaşı $\% 95 \mathrm{iken}$, tarım sigortası yaptıranlarda bu oranın yaklaşı \%94 düzeylerinde olduğu tespit edilmiştir.

Tarımda gelişen yeni teknolojilerin benimsenmesinde erken benimseyenlerin geç benimseyenlere göre eğitim seviyelerinin daha yüksek olduğu yapılan çeşitli araştırmalarla ortaya konulmuştur. Bu amaçla yapılmış olan 275 araştırmanın \%74'ünde herhangi bir tarımsal yeniliği benimseme davranışı ile eğitim düzeyi arasında olumlu bir ilişki olduğu saptanmıştır (Rogers 1983).

Üreticilerin ikamet durumları incelendiğinde, \%16,3'ünün il veya ilçe merkezinde, $\% 1,9$ 'ünün belde veya kasabada, \%81,8'inin ise köyde yaşadıkları belirlenmiştir. Tarım sigortası yaptıranlar ile yaptırmayanların yaşadıkları yerlere göre dağılımı benzer özellik göstermekte olup, bu üreticilerin \% 80'in üzerinde köyde yaşadıkları tespit edilmiştir.

Üreticilerin hane halkı sayıları incelendiğinde, yaklaşı \%91'inin 1-4 kişi arasında yoğunlaş̧ı̆̆ı, tarım sigortası yaptırmayanlarda 1-4 kişi aralığındaki oran $\% 95,5 \mathrm{iken}$, tarım sigortası yaptıranlarda bu oran, yaklaşı $\% 81$ 'dir.

Üreticilerin sosyal güvence durumları incelendiğinde, \%91,2'sinin sosyal güvenceye sahip oldukları, $\% 8,8^{\prime}$ inin ise herhangi bir sosyal güvenceye sahip olmadıkları belirlenmiştir. Tarım sigortası yaptırmayanların $\% 90,1$ ' $\mathrm{i}$ sosyal güvenceye sahip iken, tarım sigortası yaptıranlarda sosyal güvenceli olanların oranı $\% 93,7$ 'dir. Sosyal güvenceye sahip olan üreticilerin $\% 7,2$ 'sinin emekli sandığ 1 , \%37,1'inin SSK, \%16,2'sinin Esnaf Bağ-Kur ve \%39,2'sinin Tarım Bă̆-Kur'lu oldukları tespit edilmiştir.

Türkiye'de kırsal toplumda yaşayanların önemli özelliklerinden biri de geleneksel güvenlik kavramıdır. Nüfus ve arazi üzerindeki hareketlilik yalnız o günün ekonomik ve sosyal yaşantısını kurtarmak için değil, geleceğinde dikkate alındığı düşünüldüğünden ortaya çıkmıştır. Ancak zaman içerisinde miras ve mülkiyet yoluyla bölünmeler nedeniyle aile bireyleri için güvence sağlamaya yetmeyecek kadar küçük işletmelerin oluşması, ilişkilerin daha ekonomik bir düzeye oturması, fiyat artışları ve ekonomik 
gelişmeler insanların geçimi ve bakımı açısından daha iyi bir güvenceye kavuşma taleplerini hızla artırmaktadır (Aksoy ve ark. 1994).

Üreticilerin emeklilik durumları incelendiğinde, \%38,9'unun emekli, \%61,1'inin ise emekli olmadıkları, tarım sigortası yaptırmayanlarda emeklilik oran $\% 37,2$ iken, tarım sigortas yaptıranlarda bu oranın $\% 42,7$ olduğu belirlenmiştir.

Üreticilerin gelir durumları ile ilgili Çizelge 2 incelendiğinde, yaklaşı $\% 67$ 'sinin düşük gelir grubu olarak kabul edilebilecek olan 2000 TL ve daha altında, \%23,5'inin orta gelir olarak kabul edilebilecek olan 2 001-4 $000 \mathrm{TL}$ arasında ve yaklaşık \%10'unun ise yüksek gelir grubu olarak kabul edilebilecek olan 4000 TL'nin üzerinde aylık gelirlerinin olduğu tespit edilmiştir. Tarım sigortası yaptırmayanlarda düşük gelir olarak kabul edilen gelir grubunun oranı yaklaşı $\% 79$ olurken, bu oran tarım sigortası yaptıranlarda $\% 37,5^{\prime}$ tir. Tarım sigortası yaptırmayanlarda yüksek gelir grubunun oranı $\% 2,7 \mathrm{iken}$, sigorta yaptıranlarda bu oranın $\% 26$ olduğu belirlenmiştir. Tarımsal faaliyetten elde edilen gelir oranı $\% 50$ ve altında olan üreticilerin oranı yaklaşı \% $\% 5$ iken, \%50'nin üzerinde olanların oranı ise yaklaşık \%55'dir. Burada en büyük payın \%32 ile tarımsal faaliyetten elde edilen gelir oranı $\% 76$ ile $\% 100$ arasındaki üreticilerde olduğu, tarım sigortası yaptırmayan üreticiler içerisinde tarımsal faaliyetten elde edilen gelir oran1 \%50'nin üzerinde olanların oranı $\% 51,6 \mathrm{iken}$, tarım sigortası yaptıranlarda bu oranın $\% 63,5$ olduğu belirlenmiştir. Buradan anlaşılacağı üzere gelir artıkça tarım sigortası yaptırma eğilimi de artmaktadır.

Çizelge 2. Üreticilerin toplam aylık gelir durumlarına göre dağılımı (TL)

\begin{tabular}{lcccccc}
\hline $\begin{array}{c}\text { Toplam Aylık } \\
\text { Gelir }\end{array}$ & \multicolumn{2}{c}{$\begin{array}{c}\text { Tarım Sigortas } \\
\text { Yaptırmayanlar } \\
\text { Adet }\end{array}$} & \multicolumn{2}{c}{$\begin{array}{c}\text { Tarmm Sigortası } \\
\text { Yaptiranlar } \\
\text { Odet }\end{array}$} & \multicolumn{2}{c}{ Toplam } \\
\cline { 2 - 7 } $1000>$ & 46 & 20,6 & 5 & 5,2 & 51 & 16,0 \\
$1000-2000$ & 131 & 58,8 & 31 & 32,3 & 162 & 50,8 \\
$2001-4000$ & 40 & 17,9 & 35 & 36,5 & 75 & 23,5 \\
$4001-7000$ & 4 & 1,8 & 13 & 13,5 & 17 & 5,3 \\
$7000<$ & 2 & 0,9 & 12 & 12,5 & 14 & 4,4 \\
\hline Toplam & $\mathbf{2 2 3}$ & $\mathbf{1 0 0 , 0}$ & $\mathbf{9 6}$ & $\mathbf{1 0 0 , 0}$ & $\mathbf{3 1 9}$ & $\mathbf{1 0 0 , 0}$ \\
\hline
\end{tabular}

Gelir, bir kişinin belirli bir zaman dilimi içinde aynı zenginlikte kalmak koşulu ile o dönem içinde tüketebileceği mal ve hizmetlerin tamamı olarak tanımlanmaktadır (Açı1 1984).

Üreticilerin tarım dışı faaliyet durumları incelendiğinde, \%58,6'sının tarım dışı bir faaliyette bulunmadığı, \%41,4'ünün ise bulunduğu, tarım sigortası yaptırmayan üreticiler içerisinde tarım dış1 faaliyette bulunanların oranı $\% 37,7$ iken, tarım sigortası yaptıranlarda bu oranın $\% 50$ olduğu belirlenmiştir. Tarım dışında faaliyet gösteren üreticilerin $\% 19,7$ 'sinin bu faaliyetlerini kamu sektöründe, \%3,8'inin özel sektörde, \%11,4'ünün esnaf ve $\% 65$, ' 'inin serbest çalışanlar, tarım sigortası yaptıran ve yaptırmayanlar benzer özellikler göstermekte olup, bunlar içerisindeki en yüksek orana sahip grubun serbest çalışanlar olduğu belirlenmiştir.

\subsection{Fındık üretimi yapan işletmelerin yapısal özellikleri}

Üreticilerin sahip oldukları fındık arazisi miktarları incelendiğinde, \%16'sının toplam findık arazisinin $0-5 \mathrm{da}, \% 28,5$ 'inin ise 11-20 da arasında olduğu ve bu grubun oran olarak en yüksek grup olduğu, bir başka açıdan bakıldığında üreticilerin yaklaşı \%83'ünün findık arazisinin 36 dekarın altında olduğu belirlenmiştir. Tarım sigortası yaptırmayanlarda 35 dekarın üzerinde arazisi olanların oranı $\% 9$ iken, tarım sigortası yaptıranlarda bu oran yaklaşı \%35 düzeyindedir. Buradan da anlaşılacağı üzere findık arazisi alanı artıkça tarım sigortası yaptırma eğilimi yükselmektedir.

Samsun ili Terme ilçesinde çiftçilerin risk davranışlarını ortaya koyan çalışmada 52 çiftçi ile anket yapılmış olup, çiftçilerin risk davranışlarının belirlenmesinde Referans Kumarı (Reference Gamble) ve davranış ölçeklerinden yararlanılmıştır. Analiz sonucunda çiftçilerin \%38,46'sının risk seven, \%59,61'inin risk karşıtı ve \%1,93'ünün riske tepkisiz olduğu tespit edilmiştir. Çiftçilerin riske karşı olma derecelerini aile büyüklüğü, arazi büyüklüğü, dekara tarımsal gelir ve fikir önderliğinin pozitif yönde, tarımsal gelirin ise negatif yönde etkilediği belirlenmiştir. Çiftçilerin riski sevme derecelerini ise arazi büyüklüğü ve tarım dışı gelirin pozitif yönde, eğitim ve dekara tarımsal gelirin negatif yönde etkilediği tespit edilmiştir (Ceyhan vd 1996).

Arazi, tarımsal üretim araçları arasında en önemlisi ve vazgeçilmez olanıdır. İşletme arazisi, mülkiyet ilişkisi, arazinin cinsleri ve yararlanma durumları dikkate alınmaksızın çiftçi ailesinin işlettiği toplam alandır (Tatlıdil 1992). Rogers (1983) yapmış olduğu bu çalışmada, erken benimseyenlerin geç benimseyenlere oranla daha büyük işletmelere sahip oldukları sonucuna ulaşmıştır. Üreticilerin karar 
vermeleri üzerinde etkili olan faktörleri inceleyen araştırmalarda da benzer sonuçlara ulaşılmıştır (Konyar and Osborn 1990; Boz 1993; Thungwa 2000).

Üreticilerin findık bahçelerinde geçirdikleri zaman süreleri incelendiğinde, $\% 8,8$ 'inin findık bahçelerinde yılda 1 aydan daha az, \%62'sinin ise 3 ay veya daha az zaman geçirerek findığa bakım yaptıkları, findık bahçelerinde yılda 6 ay veya daha fazla zaman geçirenlerin oranı ise yaklaşı \%17 olduğu belirlenmiştir. Tarım sigortası yaptırmayanlarda yılda 3 ay veya daha az zaman geçirenlerin oranı yaklaşı \%66 iken bu oran sigorta yaptıranlarda yaklaşık \%52'dir. Bunun yanında tarım sigortası yaptırmayanlarda 6 ay veya daha fazla zaman geçirenlerin oranı $\% 12,5 \mathrm{iken}$, tarım sigortası yaptıranlarda bu oran ise yaklaşı $\% 28$ 'dir.

Üreticilerin findık tarımı dışında diğer bitkisel üretim faaliyeti yapıp yapmadıkları durumu incelendiğinde, \%68'inin findık tarımı dışında diğer bitkisel üretim faaliyeti yapmadıkları, \%32'sinin ise yaptıkları tespit edilmiştir. Tarım sigortası yaptırmayanlarda fındık dışı diğer bitkisel üretim faaliyetinde bulunanların oranı $\% 32,3 \mathrm{iken}$, tarım sigortası yaptıranlarda bu oran $\% 31,3$ olduğu ve birbirleri arasında pek bir farkın bulunmadığı belirlenmiştir. Fındık dışı diğer bitkisel üretim faaliyeti yapanların en çok $\% 30,9$ oranıyla dane mısır ve \%29,4 oranıyla sebzecilik faaliyeti yaptikları, tarım sigortas yaptırmayanların en çok $\% 34,4$ ile sebzecilik faaliyeti, tarım sigortası yaptıranların ise $\% 25,6$ oranı ile dane mısır üretimi yaptıkları belirlenmiştir.

Üreticilerin ortakçılık/yarıcılık faaliyet ile ilgili tercihleri incelendiğinde, \%89'nun ortakçılık/yarıcıllık yapmadıkları, \%11'inin ise yaptıkları, tarım sigortası yaptırmayanlarda ortakçılık/yarıcılık faaliyetinde bulunanların oranı $\% 8,1 \mathrm{iken}$, tarım sigortası yaptıranlarda bu oranın $\% 17,7$ olduğu belirlenmiş̧ir.

Üreticilerin büyükbaş hayvancilık faaliyeti ile ilgili tercihleri incelendiğinde, \%70,2'sinin büyükbaş hayvancılık faaliyeti yapmadıkları, \%29,8'inin ise yaptıkları, tarım sigortası yaptırmayanlarda büyükbaş hayvancılık faaliyetinde bulunanların oranı $\% 26,9 \mathrm{iken}$, tarım sigortası yaptıranlarda bu oranın $\% 36,5$ olduğu belirlenmiştir. Büyükbaş hayvancılık faaliyeti yapan üreticilerin içerisinde en yüksek oranın $\% 28,4$ ile 2 büyükbaş hayvana sahip olan üreticilerin olduğu tespit edilmiştir. Tarım sigortası yaptırmayanlara bakıldığında en yüksek oranın \%33,3 ile 2 baş büyükbaş hayvana sahip üreticilerin olduğu, tarım sigortası yaptıranlarda ise en yüksek oranın $\% 22,9$ oranları ile 3 ve 5 baş büyükbaş hayvana sahip olan üreticilerin olduğu tespit edilmiştir.

Üreticilerin küçükbaş hayvancıllk faaliyeti ile ilgili tercihleri incelendiğinde, \%98,4'ünün küçükbaş hayvancılık faaliyeti yapmadıkları, \%1,6'sının ise yaptıkları, tarım sigortası yaptırmayanlarda küçükbaş hayvancılık faaliyetinde bulunanların oranı $\% 0,9 \mathrm{iken}$, tarım sigortası yaptıranlarda bu oranın ise $\% 3,1$ olduğu belirlenmiştir. Küçükbaş hayvancılık faaliyeti yapan üreticilerin içerisinde en yüksek oranın \%60 ile 5 baş hayvandan daha az sayıda küçükbaş hayvana sahip olan üreticilerin oluşturduğu tespit edilmiştir. Tarım sigortası yaptırmayanlarda her iki oranın eşit olduğu, tarım sigortası yaptıranlarda ise en yüksek oranın \%66,7 oranı ile 5 baş hayvandan daha az sayıda küçükbaş hayvana sahip olan üreticilerin oluşturduğu belirlenmiş̧ir.

Üreticilerin arıcılık faaliyeti ile ilgili tercihleri incelendiğinde, \%96,2'sinin arıcılık faaliyeti yapmadıkları, \%3,8'sının ise yaptıkları, tarım sigortası yaptırmayanlarda arıcılık faaliyetinde bulunanların oranı $\% 3,1 \mathrm{iken}$, tarım sigortası yaptıranlarda bu oranın $\% 5,2$ olduğu belirlenmiştir. Arıc1lık faaliyeti yapan üreticilerin içerisinde en yüksek oranın \%41,6 ile 1-2 kovana sahip üreticilerin oluşturduğu, tarım sigortası yaptırmayanlarda oranların birbirine çok yakın olduğu, tarım sigortası yaptıranlarda ise en yüksek oranın \%60 ile 1-2 kovana sahip olan üreticilerin olduğu belirlenmiştir.

Üreticilerin tavukçuluk faaliyeti ile ilgili tercihleri incelendiğinde, \%96,9'unun tavukçuluk faaliyeti yapmadıkları, \%3,1'inin ise yaptıkları belirlenmiştir. Tarım sigortası yaptırmayanlarda tavukçuluk faaliyetinde bulunanların oranı $\% 1,3$ iken, tarım sigortası yaptıranlarda bu oranın \%7,3'dir. Buradan da anlaşılacağı üzere tavukçuluk faaliyeti yapanların oranı artıkça tarım sigortası yaptırma eğilimi yükselmektedir.

Üreticilerin findık toplama tercihleri incelendiğinde, \%45,4'ünün ürünlerini aileleriyle birlikte, $\% 11,4$ 'ünün komşularıyla birlikte, \%11,7'sinin gündelikçilere toplattırdıkları ve $\% 31,5$ 'inin ise mevsimlik işçilere toplattırdıkları belirlenmiştir. Tarım sigortası yaptırmayanlarda findık toplama şeklinin en yüksek oranda $\% 50$ ile aile ile birlikte toplama şeklinde olduğu, tarım sigortası yaptıranlarda ise en yüksek oranda $\% 44,7$ oranı ile ürünlerini mevsimlik işçilere toplattırdıkları tespit edilmiş̧ir.

Üreticilerin tarımsal afetten zarar görme durumları ile ilgili Çizelge 3 incelendiğinde, \%53'ünün tarımsal afetten zarar görmediği, \%47'sinin ise zarar gördüğü belirlenmiştir. Tarım sigortası yaptırmayanlarda tarımsal afetten zarar görenlerin oran $\% 31,8$ iken, tarım sigortası yaptıranlarda ise bu oranın oldukça yüksek bir oranda ortaya çıktığı ve $\% 82,3$ olduğu tespit edilmiş̧tir. Buradan da anlaşılacağı üzere tarımsal afetten zarar görenlerin tarım sigortası yaptırma olasıllğı daha yüksektir. 
Çizelge 3. Üreticilerin tarımsal afetten kaynaklanan zarar durumlarına göre dağılımı

\begin{tabular}{lcccccc}
\hline \multirow{2}{*}{ Tarımsal Afet Zararı } & \multicolumn{2}{c}{ Tarım Sigortası } & \multicolumn{2}{c}{ Tarım Sigortası } & \multicolumn{2}{c}{ Toplam } \\
& \multicolumn{2}{c}{ Yaptırmayanlar } & \multicolumn{2}{c}{ Yaptıranlar } & & \\
\cline { 2 - 7 } & Adet & Oran (\%) & Adet & Oran (\%) & Adet & Oran (\%) \\
Hayır & 152 & 68,2 & 17 & 17,7 & 169 & 53,0 \\
Evet & 71 & 31,8 & 79 & 82,3 & 150 & 47,0 \\
\hline Toplam & $\mathbf{2 2 3}$ & $\mathbf{1 0 0 , 0}$ & $\mathbf{9 6}$ & $\mathbf{1 0 0 , 0}$ & $\mathbf{3 1 9}$ & $\mathbf{1 0 0 , 0}$ \\
\hline
\end{tabular}

Küresel ısınmanın meydana getirdiği iklimsel bozuklukların bitkisel faaliyeti olumsuz yönde etkileyebileceği, meteorolojik araştırmalara göre iklim değişikliğinin daha şiddetli olacağı ve 1990-2100 tarihlerini kapsayan periyotta küresel yüzey 1 sısının $1,4-5,8^{\circ} \mathrm{C}$ arasında değişen oranlarda artacağının hesaplandığı, küresel ısınmada insan faktörünün en başta geldiği, önlem alınmadığı takdirde bu ısınmaların etkisiyle mevsimler arasındaki sıcaklık farklarının azalacağı, bunun da başta sel ve kuraklık gibi doğal afetleri ortaya çıkaracağ 1 ve başta tarım sektörü olmak üzere tüm sektörlerin zarar göreceği belirtilmiştir (Dinler 2005).

Üreticilerin ürünlerinde meydana gelen zararları nedeniyle, tarım sigortası dışında devlet tarafından yapılan herhangi bir yardımından faydalanma durumları incelendiğinde, $\% 86,5$ 'inin devlet yardımından faydalanmadıkları, \%13,5'inin ise faydalandıkları belirlenmiştir. Tarım sigortası yaptırmayanlarda devlet yardımından faydalananların oranı $\% 15,7 \mathrm{iken}$, tarım sigortası yaptıranlarda bu oranın $\% 8,3$ olduğu tespit edilmiştir. Buradan da anlaşılacağı üzere devlet, tabii afetlerden zarar gören üreticilere tarım sigortası dışında nakdi veya ayni yardım yaptıkça, üreticiler nasılsa devlet yardım yapıyor, tarım sigortası yaptırmaya gerek yok düşüncesine kapılmaktadır. Bu nedenlerden ötürü de devlet yardım yaptıkça tarım sigortası yaptırma eğilimi düşmektedir.

\subsection{Fındık üretimi yapan işletmelerin bilgi kaynaklarına olan yaklaşımı}

Üreticilerin tarımsal danışmanlık sisteminden faydalanma tercihleri incelendiğinde, \%90,3'ünün tarımsal danışmanlık hizmetinden faydalanmadıkları, $\% 9,7$ ise faydalandıkları belirlenmiştir. Tarım sigortası yaptırmayanlarda tarımsal danışmanlık hizmetinden faydalananların oranı \%6,7 iken, tarım sigortası yaptıranlarda bu oranın $\% 16,7$ olarak tespit edilmiştir.

Üreticilerin tarımsal kredi kullanma tercihleri ile ilgili Çizelge 4 incelendiğinde, \%41,4'ünün tarımsal kredi kullanmadıkları, \%58,6'sının ise kullandıkları belirlenmiştir. Tarım sigortası yaptırmayanlarda tarımsal kredi kullananların oranı $\% 50,2$ iken, tarım sigortası yaptıranlarda bu oranın $\% 78,1$ olduğu tespit edilmiştir. Buradan da anlaşılacağı üzere tarımsal kredi kullanma oranı artıkça tarım sigortası yaptırma eğilimi yükselmektedir. Kredi kullanan üreticilerin en çok krediyi \%62,6 ile Ziraat Bankası aracilığıyla kullandıkları, bunu \%26,7 ile Tarım Kredi Kooperatifinin izlediği ve en az kullanılan kaynağın ise \%10,7 ile diğer banka kaynakları olduğu belirlenmiştir. Tarım sigortası yaptıran ve yaptırmayanlar arasında kredi kullanma kaynağı açısından pek bir fark olmayıp, her iki durumda da en çok kullanılan kaynağın Ziraat Bankası kaynağı olduğu tespit edilmiştir.

Çizelge 4. Üreticilerin tarımsal kredi kullanım durumlarına göre dağılımı

\begin{tabular}{lccccccc}
\hline \multicolumn{1}{c}{$\begin{array}{c}\text { Tarımsal Kredi } \\
\text { Kullanım Durumu }\end{array}$} & \multicolumn{2}{c}{ Tarım Sigortası } & \multicolumn{2}{c}{ Tarım Sigortası } & \multicolumn{2}{c}{ Toplam } \\
\cline { 2 - 7 } & \multicolumn{2}{c}{ Yaptırmayanlar } & \multicolumn{2}{c}{ Yaptıranlar } & & \\
\cline { 2 - 8 } Hayir & Adet & Oran (\%) & Adet & Oran $(\%)$ & Adet & Oran (\%) \\
Evet & 111 & 49,8 & 21 & 21,9 & 132 & 41,4 \\
Toplam & 112 & 50,2 & 75 & 78,1 & 187 & 58,6 \\
\hline
\end{tabular}

Ankara ili Polatlı ilçesinde üreticilerin tarım sigortası yaptırmaya karar verme sürecinde etkili olan faktörler olarak, üreticilerle ilgili bireysel niteliklerden kredi kullanımı ve tarım dışı gelirin, işletme özelliklerinden ise hayvan varlığı ve şeker pancarı ekim alanının tarım sigortası yaptırmaya karar vermede etkili olan faktörler olduğu, bunun yanında devlet tarafından verilen prim desteğinin tarım sigortasına karar vermede etkili olduğu belirlemiștir (Yavuz 2010).

Üreticiler, tarımsal üretimin devamlılığını sağlayabilmek adına üretim dönemi boyunca gereksinim duyacakları girdi ve finansman desteğini sağlayabilmek için işletme dışı kaynaklara başvurabilirler. Türkiye'de bu kaynakların başında öncelikle T.C. Ziraat Bankası ve Tarım Kredi Kooperatifleri gelmektedir (Boz 1993).

Tarımsal üretimi artırmanın, üstün kaliteli ürün elde etmenin ve tarımda çalışanların yaşam düzeylerini yükseltmenin en önemli yollarından biri üreticilerin örgütlenmesidir (Karlı ve Çelik 2003). 
Üreticilerin zorunlu üyelik durumu olan Ziraat Odası dışında kalan tarımsal örgütlere üye olma tercihleri incelendiğinde, \%41,7'sinin herhangi bir tarımsal örgüte üye olmadıkları, \%58,3'ünün ise üye oldukları belirlenmiştir. Tarım sigortası yaptırmayanlarda herhangi bir tarımsal örgüte üye olanların oranı $\% 52,5$ iken, tarım sigortası yaptıranlarda bu oranın \%71,9 olarak tespit edilmiştir. Tarımsal örgüte üye olan üreticilerin \%19,7'sinin tarımsal kalkınma kooperatifine, \%60,1'inin tarım kredi kooperatifine, \%18,4'ünün Fiskobirliğe, \%1,3'ünün üretici birliğine ve \%0,5'ünün ise yetiştirici birliğine üye oldukları tespit edilmiştir. Tarım sigortası yaptıran ve yaptırmayanlar arasında üye olunan örgüt türü açısından pek bir fark olmayıp, her iki durumda da en çok üye olunan örgüt türünün tarım kredi kooperatifi olduğu belirlenmiştir.

Haberleşme vasıtaları bir yeniliği erken benimseyenler için oldukça önemlidir. Yenilikler bir sosyal sisteme dışardan girer, ilk benimseyenler kozmopolit kanalları kullananlardır. Kitle iletişim araçları tamamen kozmopolit kanallardır (Taluğ ve Tatlıdil 1993).

Üreticilerin internet tercihleri incelendiğinde, \%62,4'ünün internet kullanmadıkları, \%37,6'sının ise kullandıkları belirlenmiştir. Tarım sigortası yaptırmayanlarda internet kullananların oranı \%32,3 iken, tarım sigortası yaptıranlarda bu oranın \%50 olduğu tespit edilmiştir. Buradan da anlaşılacağı üzere internet kullanma oranı arttıkça tarım sigortası yaptırma eğilimi yükselmektedir.

Üreticilerin kasko tercihleri incelendiğinde, \%78,7'sinin kasko yaptırmadıkları, \%21,3'ünün ise yaptırdıkları belirlenmiştir. Tarım sigortası yaptırmayanlarda kasko yaptıranların oranı $\% 14,8 \mathrm{iken}$, tarım sigortası yaptıranlarda bu oran \%36,5'dir.

Üreticilerin bireysel emeklilik tercihleri incelendiğinde, \%95,6'sının bireysel emeklilik yaptırmadıkları, \%4,4'ünün ise yaptırdıkları belirlenmiştir. Tarım sigortası yaptırmayanlarda bireysel emeklilik yaptıranların oranı $\% 2,2$ iken, tarım sigortası yaptıranlarda bu oran $\% 9,4$ 'dur. Buradan da anlaşılacağ 1 üzere bireysel emeklilik yaptıranların oranı artıkça tarım sigortası yaptırma eğilimi yükselmektedir.

Üreticilerin tarım sigortası bilgi düzeyleri incelendiğinde, \%15'inin tarım sigortası konusunda bilgilerinin olmadığı, \%71,8'inin kısmen, \%13,2'sinin ise yeterli bilgilerinin olduğu belirlenmiştir. Tarım sigortası yaptırmayanlarda, sigorta konusunda yeterli bilgisi olan üreticilerin oranı $\% 4,9 \mathrm{iken}$, tarım sigortası yaptıranlarda bu oran \%32,3'dur. Buradan da anlaşılacağı üzere tarım sigortası konusunda bilgisi olanların oranı artıkça tarım sigortası yaptırma eğilimi yükselmektedir. Bilgi sahibi olan üreticilerin $\% 10,3$ 'ünün bu bilgiye 1 yıldan beri sahip oldukları, \%24,7'sinin 2 yıldan beri, $\% 22,9$ 'unun 3 ylldan beri, \%12,2'sinin 4 yıldan beri, \%14'ünün 5 yıldan beri, \%3'ünün 6 yıldan beri ve $\% 12,9$ 'unun 7 yıl ve daha fazla yıldan beri sahip oldukları tespit edilmiştir. Tarım sigortası yaptıran ve yaptırmayanlar açısından bilgi sahibi olma durumları yıllara göre değişmekte ve sigorta yaptırıp ve yaptırmama konusunda bu değişkenin etkili olmadığı belirlenmiştir. Üreticilerin tarım sigortası konusunda bilgi kaynakları olarak en yüksek oranın \%40,7 ile Tarım Müdürlüğü olduğu, ardından \%11,6 ile TARSiM' in geldiği, tarım sigortası yaptıran ve yaptırmayanlar açısından aralarında önemli bir fark olmadığı ve en önemli bilgi kaynağının Tarım Müdürlüğü olduğu belirlenmiştir. Tarım sigortası yaptırmayanlarda bilgi kaynağı olarak TARSIM olanların oran $1 \% 8,8$ iken sigorta yaptıranlarda bu oran \%16'dır.

Üreticilerin tarım sigortası eğitimine katılma durumları incelendiğinde, \%54,9'unun tarım sigortası konusunda eğitim almadıkları, \%45,1'inin ise aldıkları belirlenmiştir. Tarım sigortası yaptırmayanlarda eğitim alanların oranı $\% 41,3 \mathrm{iken}$, tarım sigortası yaptıranlarda bu oranın $\% 54,2$ olduğu tespit edilmiştir. Üreticilerin \%48,6'sının tarım sigortası konusunda eğitim almak istemedikleri, \%51,4'ünün ise istedikleri belirlenmiştir. Tarım sigortası yaptırmayanlarda eğitim almak isteyenlerin oranı $\% 44,4 \mathrm{iken}$, tarım sigortası yaptıranlarda bu oranın \%66,7 olduğu tespit edilmiştir. Buradan da anlaşılacağı üzere tarım sigortası konusunda eğitim almak isteyenlerin oranı arttıkça tarım sigortası yaptırma eğilimi yükselmektedir.

\section{Sonuç ve Öneriler}

Tarım sigortaları uygulamalarının henüz daha yeni olması nedeniyle, üreticilerin olası bir tabii afet durumunda ürünlerinde meydana gelecek zararlarının karşılanması için tarım sigortası yaptırmaları yönünde bilinç uyandırmak ve bu uygulamayı yaygınlaştırmak amacıyla Düzce ilinde tarım sigortası yaptıran ve yaptırmayan üreticilerin karşılaştırmalı analizleri yapılmıştır. Bu kapsamda, tarım sigortası yaptıran 96 ve yaptırmayan 223 olmak üzere toplam 319 üreticiden anket yöntemi ile veriler toplanmıştır. Araştırma bölgesindeki üreticilerin bireysel özellikleri, işletme özellikleri ve bilgi kaynaklarına yaklaşımları dikkate alınarak oransal dağlımlar yapılmıștır. Oransal dağlımlar ile ilgili yapılan analizler sonucunda; bireysel özellikleri değişkenlerinden özellikle toplam aylık gelir değişkeninin tarım sigortası yaptıran ve yaptırmayan üreticiler arasında önemli ölçüde ayrıştı̆̆ı, tarım sigortası yaptırmayanlarda düşük gelir olarak kabul edilen gelir grubunun oranı yaklaşı \%79 olurken, bu oran tarım sigortası yaptıranlarda $\% 37,5^{\prime}$ tir. Tarım sigortası yaptırmayanlarda yüksek gelir grubunun oranı $\% 2,7 \mathrm{iken}$, bu oran sigorta yaptıranlarda $\% 26$ olduğu belirlenmiştir. 
İşletme özellikleri değişkenlerinden toplam fındık arazisi miktarı, tarımsal afet zararı ve devlet yardımından faydalanma değişkenleri öne çıkmıştır. Tarım sigortası yaptırmayanlarda 35 dekarın üzerinde arazisi olanların oranı $\% 9$ iken, tarım sigortası yaptıranlarda bu oran yaklaşık $\% 35$ düzeyindedir. Tarım sigortası yaptırmayanlarda tarımsal afetten zarar görenlerin oranı $\% 31,8 \mathrm{iken}$, tarım sigortası yaptıranlarda ise bu oranın oldukça yüksek bir oranda ortaya çıktığı ve bu oranın \%82,3 olduğu, tarım sigortası yaptırmayanlarda dışındaki devlet yardımından faydalananların oranı \% $15,7 \mathrm{iken}$, tarım sigortası yaptıranlarda bu oranın \% 8,3 olduğu belirlenmiştir. Devletin başta afet yardımı ve borç erteleme gibi uygulamaları tarım sigortası yaptırmak isteyen üreticileri olumsuz etkilemekte olduğundan TARSIM dışındaki tüm yardım mekanizmalarının kaldırılması ve tarımsal desteklemelerde sigorta yaptırma şartının getirilmesi tarım sigortalarının yaygınlaşmasına önemli katkılar yapacaktır.

Bilgi kaynaklarına yaklaşım değişkenleri içerisinde yer alan değişkenlerden özellikle tarımsal kredi kullanımı değişkenin öne çıktığı ve tarım sigortası yaptırmayanlarda tarımsal kredi kullananların oranı $\% 50,2$ iken, tarım sigortası yaptıranlarda bu oranın \%78,1 olduğu belirlenmiştir.

Yapılan bu çalışma, Düzce ilinde tarım sigortası yaptıran ve yaptırmayan üreticilerin bireysel özellikleri, işletme özellikleri ve bilgi kaynaklarına yaklaşım özellikleri bakımından karşılaştırıldıklarında aralarında önemli oranda farklılıklar olduğu sonucunu ortaya koymuştur. Araştırma sonucunda ortaya çıkan sonuçların, gelecekte bu konuda çalışma yapmak isteyen tüm kesimlere yol gösterici nitelikte olacaktır.

\section{Kaynaklar}

Açıl, F. A., (1984). Ekonomi I (Genel Ekonomi) Ders Kitabı. Ankara Üniversitesi Ziraat Fakültesi Yayın1, No: 249, Ankara.

Aksoy, S., Eraktan, G., Eraktan, S., Kuhnen, F. ve Winkler, W., (1994). Türkiye'de Kırsal Nüfusun Sosyal Güvenliği. Ankara Üniversitesi Basımevi, Ankara/Göttingen.

Anonim, (2016a). Faaliyet Raporu. GTHB Düzce İl Müdürlüğü.

Anonim, (2016b). Tarım Sigortası Poliçe Verileri. GTHB Düzce İl Müdürlüğü.

Anonim, (2017). Sunum. TARSİM. https://web.tarsim.gov.tr. (Erişim Tarihi: 21.02.2017).

Boz, İ., (1993). Tarım Sigortasının Polatlı İlçesinde Yayılması ve Benimsenmesi Üzerine Bir Araştırma. Ankara Üniversitesi Ziraat Fakültesi Tarım Ekonomisi Bölümü Yüksek Lisans Tezi, Ankara.

Ceyhan, V., Cinemre, H. A. ve Demiryürek, K., (1996). Samsun İli Terme İlçesinde Çiftçilerin Risk Davranışlarının Belirlenmesi. Türkiye 2. Tarım Ekonomisi Kongresi 4-6 Eylül, Adana.

Dinler, T., Yaltırık, A., Çetin, B., Özkan, B., Gülçubuk, B., Sürmeli, E., Ekmen, E., Saner, G., Akçaöz, H., Uysal, Ö.K., Karaaslan, S. ve Kıymaz, T., (2005). Tarımda Risk Yönetimi ve Tarım Sigortaları. TMMOB Türkiye Ziraat Mühendisliği VI. Teknik Kongresi, 1209-1232, Ankara.

Eraktan, G., 1970. Türkiye'de Zirai Sigortanın Lüzum ve Önemi. A.Ü. Ziraat Fakültesi, 109-110, Ankara.

Güngör, M., 2006. Türkiye'de Tarım Sigortası Uygulamaları ve Devlet Destekli Tarım Sigortası. Yüksek Lisans Tezi, Marmara Üniversitesi, Bankacılık ve Sigortacılık Enstitüsü, Sigortacılık Anabilim Dalı, İstanbul.

Karlı, B. ve Çelik, Y., (2003). GAP Alanındaki Tarım Kooperatifleri ve Diğer Çiftçi Örgütlerinin Bölge Kalkınmasındaki Etkinliği. Tarımsal Ekonomi Araştırma Enstitüsü Yayınları, No: 97, Ankara.

Keskinkılıç, K., (2013), Tarım Sigortacılı̆̆ı: Dünya ve Türkiye'deki Uygulamaların Değerlendirilmesi. Çukurova Üniversitesi Ziraat Fakültesi Tarım Ekonomisi Bölümü Yüksek Lisans Tezi, Adana. 
Konyar, K. and Osborn, T., (1990). A National Level Economic Analysis of Conservation Reserve Program Participation: A Discrete Choice Approach. The Journal of Economics Research, 42(2): $5-12$, Washington.

Miran, B., (2002). Temel İstatistik. Ege Üniversitesi, 314s, İzmir.

Newbold, P., (1995). Statistics for Business \& Economics. Fourth Edition, Prentice-Hall.

Rogers, E. M., (1983). Diffusion of Innovation. The Free Press, New York.

Taluğ, C. ve Tatlıdil, H., 1993. Tarımsal Yayım ve Haberleşme. Ankara Üniversitesi Ziraat Fakültesi Ders Notu, Teksir No: 141, Ankara.

Tatlıdil, F., (1992). Konya İli Sulu ve Kuru Koşullardaki Tarım İşletmelerinde İşgücü, Döner Sermaye ve Traktör Güçlerine Göre Optimal İşletme Büyüklüğünün Tespiti. Ankara Üniversitesi Fen Bilimleri Enstitüsü, Doktora Tezi, Ankara.

Thungwa, S., (2000). The Decision Making on Mixed Farming Practices of Farmers in Sathing Phra. The National Research Council of Thailand, Thailand.

Yavuz, G. G., (2011). Polatıı İlçesinde Üreticilerin Tarım Sigortası Yaptırmaya Karar Verme Sürecinde Etkili Olan Faktörlerin Analizi. Doktora Tezi, Ankara Üniversitesi Fen Bilimleri Enstitüsü, Ankara.

Yazıcıŏlu, Y. ve Erdoğan, S., (2004). SPSS Uygulamalı Bilimsel Araştırma Yöntemleri. Detay Yayınc1lık, Ankara. 